\title{
Importance and methodologies of endodontic microleakage studies: A systematic review
}

\author{
Farnaz Jafari ${ }^{1}$, Sanaz Jafari ${ }^{2}$
}

\begin{abstract}
${ }^{1}$ Assistant Professor, Department of Endodontics, Dental School, Tabriz Branch, Islamic Azad University
${ }^{2}$ Assistant Professor, Orthodontics Department, Dentistry Faculty, Ilam University of Medical Sciences
\end{abstract}

Correspondence:

Orthodontics Department

Dentistry Faculty, Ilam University of Medical Sciences

dr.snz.jafari@gmail.com

Jafari F, Jafari S. Importance and methodologies of endodontic microleakage studies: A systematic review. J Clin Exp Dent. 2017;9(6):e812-9. http://www.medicinaoral.com/odo/volumenes/v9i6/jcedv9i6p812.pdf

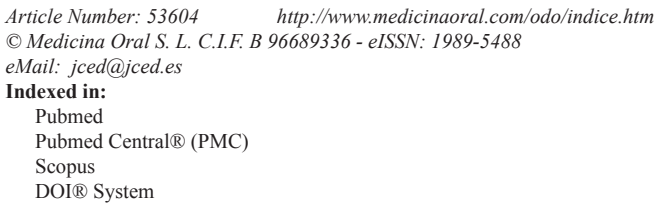

\begin{abstract}
Introduction: It is very important to obtain a tight seal in obturated root canal, making it necessary to conduct clinical or laboratory studies on the sealability of endodontic materials. Different methodologies have been historically used to assess microleakage of different endodontic materials. The aim of the present study was to comprehensively review different material testing methods used in microleakage studies, their interpretation and importance in endodontic literature.

Material and Methods: A systematic search was conducted in Medline, Cochrane, and Web of Science databases. In addition, the reference lists of review articles on the topic were searched. No language restriction was applied. Two independent reviewers screened the article.

Results: Microleakage is considered the single most important risk factor responsible for apical periodontitis. Dye penetration, dye diffusion, bacterial and endototoxin infiltration, fluid filtration, glucose, caffeine and protein infiltration, radioisotope penetration, animal studies, and electrochemical or 3D evaluation are different methodologies used to assess dental leakage. 91 out of 177 articles in the primary search were included in the study. These methods are very divergent in their viewpoints; that is why their results cannot be easily compared. It is necessary to standardize microleakage detection methods in order to more correctly evaluate the phenomena that are found between the root canal wall and the root canal filling materials.

Conclusions: All the methods are useful if studies are performed strictly with large sample sizes and proper control groups and if the technique can be standardized. Furthermore, more evaluations of the reliability of the methods are strongly recommended.
\end{abstract}

Key words: Dental leakage, review, root canal, material testing methods, data interpretation.

\section{Introduction}

The three chief aims of obturation are: 1) To entrap bacteria remaining in the root canal system; 2) To prevent the ingress of periapical tissue-derived fluid into the root canal; and 3) To prevent coronal leakage of bacteria (1). New root filling materials are developed at an attempt to improve the ability and efficacy to eliminate infections and prevent re-contamination (2). Apical periodontitis is 
not now believed to be caused by stagnation of fluid within unfilled root canal spaces (3); rather, it is believed to be an inflammatory reaction of periapical tissues and an immunologic response of the host defense system to microorganism contaminating the root canal system $(4,5)$. As a result, the success of root canal therapy critically relies on elimination of pulp space infection and contamination (6-8). Root canal infection, in a manner similar to many other infections, is mainly a biofilm-induced condition $(9,10)$. A relationship has been established between bacterial biofilms and induction of apical periodontitis by many recent histo-bacteriological studies $(11,12)$.

Extra-radicular infection, including apically extruded dentin debris in association with bacteria lodged in dentinal tubules, true radicular cysts, and foreign body reactions require surgical interventions (13).

The present review addresses the importance of microleakage in endodontics and methodologies used in endodontic microleakage studies.

\section{Material and Methods}

A systematic search was run in Medline, Biosis, Cochrane, Embase, and Web of Science databases. In addition, the reference lists of review articles on the subject were searched. No language restriction was implemented. Two independent reviewers screened the articles. Quality assessment of the included articles performed by number of citations of the articles, methodology assessment, criticism on the articles' methodologies, detailed report of the results and consistency between results and discussion part. Selected articles thoroughly studied and main topics included in the study. PRISMA flow diagram (14) for selected articles demonstrated in figure 1.

-Inclusion and exclusion criteria

Peer-reviewed journals were searched for studies on endodontic microleakage and sealability of endodontic materials published until June 2016. Studies that did not meet these inclusion criteria were excluded.

-Search methodology

Appropriate MeSH headings and key words related to the importance of sealability and different methodologies used to evaluate endodontic microleakage were used to run searches in PubMed/Medline, Biosis, Cochrane, Embase, and Web of Science databases.

Moreover, a hand search was carried out in the last 2 years of issues of the following endodontic journals: International Endodontic Journal; Journal of Endodontics; Oral Surgery, Oral Medicine, Oral Pathology, Oral Radiology and Endodontology; Brazilian Journal of Endodontics and Journal of Dental Materials. Crossreferencing process continued until no new articles were identified. Keywords included dental leakage, root canal, material testing methods, data interpretation, importance, microleakage, dye microleakage, endodontics,

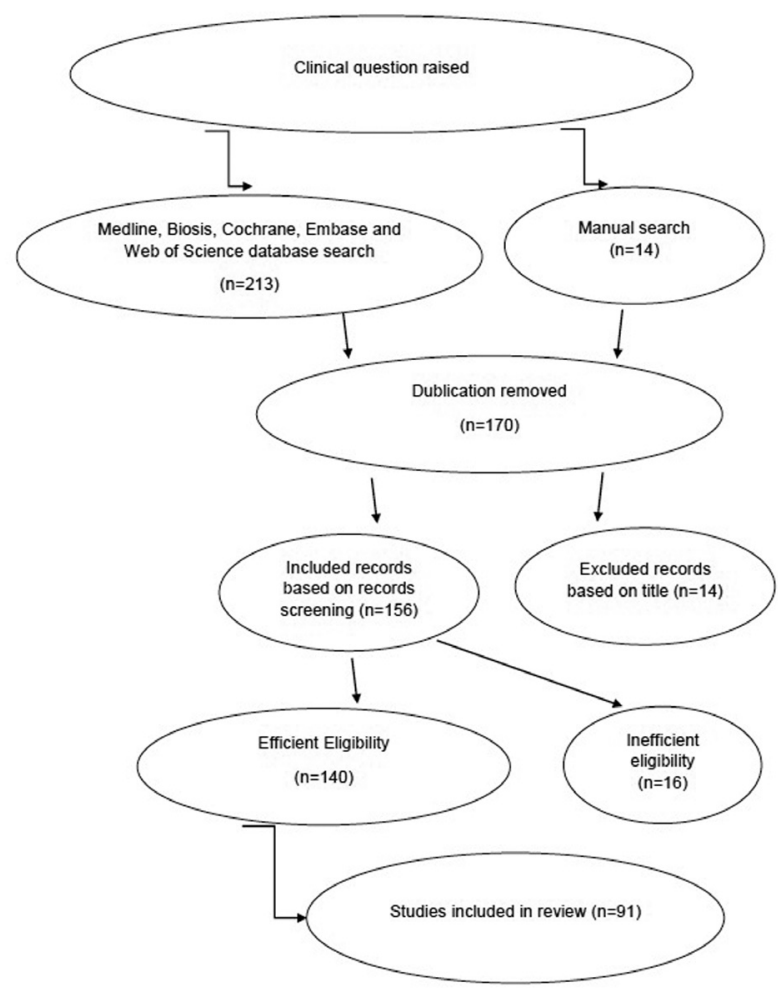

Fig. 1: PRISMA Flow Diagram for selected articles.

protein leakage, glucose leakage, fluid filtration, dye extraction, bacterial leakage, endotoxin microleakage, protein microleakage, radio-isotope, animal study, scaning electron microscope and cone beam computed tomography.

This primary search yielded 177 papers until June 2016, 86 were excluded due to inconsistency to the topic. The remaining 91 met authors' inclusion criteria and were included in this study. PRISMA flow diagram (14) for selected articles stated in figure1.

\section{Results}

-Importance

One of the goals of root canal obturation is to obtain a hermetic seal of the root canal system to induce apical and periapical healing after endodontic treatment (15). Inadequate filling and obturation might result in penetration of fluids into the voids, inducing a periapical chronic inflammatory reaction and interfering the treatment success (16).

Root canal ramifications, such as lateral, secondary and accessory canals, can establish communication pathways between the main root canal and periodontal ligament, as well as the apical foramen $(17,18)$. Several authors have reported that localized periodontal problems might arise due to the presence of necrotic and infected root canal ramifications, indicating the importance of the penetration of endodontic sealers into these irregularities 
$(17,19)$. Although this physical property is very important, no study has evaluated the relationship between the sealer's flow and its ability to penetrate into narrow root canal ramifications $(17,20)$.

-Microleakage assessment methodologies

-Methodologies that use dyes

The methodology that uses tooth immersion in various types of dyes ( $5 \%$ eosin, $0.5-2 \%$ methylene blue, $0.5-1 \%$ black India ink, blue ink, black ink, drawing ink, Procion brilliant blue, $0.5 \%$ Rhodamine $\mathrm{B}, 0.5 \%$ fuchsin and others) is easy to perform (21-30). The teeth are sectioned longitudinally or transversely or cleared and the linear penetration of the dye is recorded (31-33). The disadvantages of longitudinal dentinal sectioning seem to be the random nature of selecting the cut axis and the very low odds of the sections being cut through the deepest dye penetration point, resulting in underestimation of leakage and achieving unreliable data (34). Depth of penetration can be assessed under a stereomicroscope at $\times 4$ to $\times 30$ magnifications with all the dyes $(35,36)$. Confocal laser scanning microscope can be used for fluorescent dyes like Rhodamine B (22,37), photography and calculation using the ImageJ program (38).

Thermocycling or mechanical cycling have been used in some microleakage studies to better simulate clinical situations (39).

-Transverse sectioning to assess apical microleakage

The whole surface of each root was coated with two layers of nail varnish with different colors except for 3 $\mathrm{mm}$ from the root apex. The teeth were then immersed in a $50 \mathrm{wt} \%$ of silver nitrate $\left(\mathrm{NO}_{3} \mathrm{Ag}_{2}\right)(40)$ solution for 1 hour in a dark environment, followed by rinsing under distilled running water for 1 minute to eliminate the silver ions from the surface. Then, the teeth were immersed in a photo-developing solution and exposed to light for 12 hours. The teeth were then rinsed in distilled water and the roots were sectioned transversely at $1-\mathrm{mm}$ intervals using a low-speed diamond disc. The sections resulted in three slices labeled A, B and C and considered first, second and third based on their distance from the apex. Each slice was divided into 4 equal parts and evaluated under a stereomicroscope at $\times 30$. Dye penetration was scored as $0,1,2,3$ or 4 based on the amount of microleakage (1).

The clearing technique allows a 3D view of the internal anatomy of root canals with no loss of the tooth substance, facilitating visualization of the leakage area. It is a simple and fast technique, with no need for complex equipment (41). The technique facilitates observation of the lateral and accessory canals $(31,42,43)$, clearly revealing the relationship between the sealing material and the apical foramen. The disadvantage is deficient demineralization (44), compromising the final transparency of the specimen. This technique is more accurate than the transverse sectioning for detecting apical leakage since it reveals leakage in fractions of millimeter, while transverse sectioning only determines the presence or absence of leakage (21).

-Dye selection

In relation to dyes, particle molecular size, $\mathrm{pH}$ and chemical reactivity affect the degree of penetration (32). A large number of studies have used methylene blue as a dye $(28,34,45)$ because it is inexpensive, easy to handle, has a high degree of staining (46) and has a molecular weight lower than that of bacterial toxins (47). Some researchers have suggested that methylene blue exhibits leakage similar to butyric acid (48), a microbial metabolic product with greater penetration than Indian ink. This dye has some disadvantages such as dissolution during the demineralization and clearing processes; in addition, it is difficult to observe its maximum penetration point in some cases (49). A number of studies have suggested that Rhodamine $\mathrm{B}$ be used instead of methylene blue (50). One study reported that drawing ink exhibited less penetration into the root dentin compared to all the others (24). The particle size of this dye $(0.1-2 \mu \mathrm{m})$ is comparable to the size range of a number of endodontic pathogens and appears to be advantageous in endodontic dye leakage studies (24). On the other hand, Barthel et al (51) propounded that the particle size of the dye might not be an important factor in leakage studies.

India ink particles with diameters $\leq 3 \mu \mathrm{m}$ are also widely used $(36,49)$. It has been reported that the weight and size of India ink molecules are less than those of bacterial components isolated from the root canals. Therefore, it might not precisely simulate the molecules of fluids originating from periradicular tissues, yielding falsepositive results during leakage studies (52).

An important consideration in relation to dye penetration studies is that air trapped in voids within the root canal obturation material might interfere with fluid movement. It has been recommended that dye penetration studies should be carried out under reduced pressure, erroneously referred to as vacuum (53). However, it is difficult to eliminate the trapped air by applying low pressure to small empty spaces, including those measuring $2 \mu \mathrm{m}$ in diameter, which are permeable to bacteria (53). Kontakiotis et $a l$. (45) investigated the influence of hydration on voids within the root canal obturation materials using a fluid transport model and dye penetration, in which air was applied to eliminate water from the voids in one group and showed that methylene blue penetrated more easily into dry gaps than into water-filled gaps. Methylene blue penetrated along air-filled gaps by capillary action, whereas it penetrated into water-filled gaps by diffusion (21). It has been reported that the vacuum method gave rise to significantly more dye penetration compared to fluid filtration and passive dye penetration (54).

-Fluid filtration or transportation method

In this method, the sealing ability is measured via air 
bubble movement within a capillary tube $(21,55-58)$, consisting of an obturated canal with its coronal portion connected to a tube filled with water at atmospheric pressure, and its apex connected to a $20-\mu \mathrm{L}$ glass capillary tube measuring $170 \mathrm{~mm}$ in length and with a uniform caliber filled with water. A pressure of $0.1 \mathrm{~atm}$ is applied through the coronal part, forcing the water through the empty spaces along the root canal (53). The results are reported in $\mu \mathrm{L} / \mathrm{min}$ (59). The air bubble movements can be observed by computer-controlled diode laser beams rather than visually (21). Apical leakage can be measured with the use of a computerized fluid filtration meter consisting of a laser system (60).

-Dye extraction or dissolution method

In this method, the teeth are dissolved in acids, releasing all the dyes from the interfacial areas and a spectrophotometer determines the optical density (OD) of the solution (21).

-Methodology: Artificial saliva for 24 hours, placed in $2 \%$ methylene blue dye for $72 \mathrm{~h}$. Then the specimens were washed with distilled water, the nail varnish removed, and then they were placed in 35\% nitric acid for 72 hours. Standard solutions of $1 \%, 0.5 \%, 0.005 \%, 0.002 \%$, $0.001 \%$, and $0.0005 \%$ of methylene blue in $35 \%$ nitric acid were prepared and stored for 72 hours. At the end of this time period, the liquid was centrifuged for 1 minute (200 rpm) and the supernatant was subjected to spectrophotometric analysis at $670 \mathrm{~nm}$ to analyze the amount of leakage (61).

There was no correlation between dye penetration and the fluid filtration and dye extraction techniques which determine microleakage (34). The fluid filtration technique yielded results similar to those of dye extraction because both consider the porosity of the interface between the obturation material and the root (21). Both techniques rely on quantitative measurements of liquids passing through these interfaces (21). The dye extraction technique is superior over the fluid filtration method because the filtration values tend to diminish over time as water penetrates all the irregularities until a plateau is reached (21).

-Bacteria and toxin infiltration method

Use of bacterial organisms for the evaluation of leakage (mainly coronal) is believed to be more relevant clinically and biologically compared to the dye penetration method. A wide variety of bacterial strains have been used to assess marginal leakage, yielding contradictory results, because the methods depend on the type of bacterial strains used. In addition, if the sealer exhibits antimicrobial activity, it is not possible to employ the bacterial method $(49,62)$. The systems generally consist of two chambers, making it possible to completely separate the apical and coronal ends of each specimen. The turbidity of the apical chamber broth is the first indication of bacterial contamination (63-65). If the pulp chamber be- comes contaminated, it might be a reservoir for microorganisms and toxins, giving rise to a problem in either of the two ways. First, the apical seal might be affected, resulting in the failure of the root canal treatment. Second, penetration of microorganisms and toxins through the accessory canals on the pulp chamber floor might lead to periodontal furcation involvement (66). Bacterial studies are considered qualitative rather than quantitative (21). If only one bacterium penetrates into the obturated root canal, it might multiply in the enriched broth, causing turbidity $(65,66)$. Different microorganisms have been tested to this end, including Staphylococcus epidermidis (51), Enterococcus faecalis (64,67-69), P. mirabilis (70), Candida albicans (71), Streptococcus salivarius (62), S. epidermides (70), Candida albicans (71), S. mutans, S. mitis, Prevotella melaninogenica, and Lactobacillus acidophilus (71), Actinomyces odontotylicus, Lactobacillus acidophilus, and Pseudomonas fluorescens (72), anaerobic Streptococci and Fusobacterium nucleatum (66) and the human whole saliva (63). Enterococcus faecalis is the most frequently used bacterial species. Penetration of bacteria or bacterial products might initiate or reactivate the inflammatory process (21). The molecular size of the test material must correspond to the bacteria and/ or bacterial cell wall components and/or nutrient fluids. Leakage evaluation of root-end filling materials with the use of endotoxins is another method (73). It has been reported that endotoxins penetration preceded that of bacteria into the canal system (74).

-Glucose penetration model using fluid filtration

A new method for the analysis of endodontic microleakage has been introduced that relies on the filtration rate of glucose along the root canal obturation material (75-77). In this technique, leakage is quantified with spectrophotometry (21). Another quantitative method is to measure the concentration of leaked glucose in the apical reservoir at different time intervals with the use of enzymatic glucose oxidase method (77).

Glucose was selected as a tracing agent due to its small molecular size (MW $=180 \mathrm{Da})$ and because it is a nutrient for bacteria (21). Therefore, if glucose penetrates into the root canal from the oral cavity, the bacteria surviving the root canal preparation and obturation procedures can multiply, causing periapical inflammation (21). Glucose leakage model (GLM) is considered a very sensitive and clinically relevant sealability test (77) compared to other leakage tests. However, its disadvantages include the long experimental period, the difficulty in maintaining a bacteria-free system to prevent consumption of glucose and the risk of water evaporation.

Pilot tests are necessary to assess glucose reactivity. According to Bernabé et al (78), an approximate experimental time of 60 minutes and vacuum were selected in order to make sure that no glucose reaction would take place and also to facilitate the penetration of the marker. 
However, this glucose reactivity time can be affected by the type of the material tested and it is better to repeat it for each experiment.

-Methodology: A double-chamber should be assembled to measure glucose leakage. The maxillary segment of the syringe containing the glucose solution is connected to a pressure source to create a headspace pressure of $103 \mathrm{kPa}$ per 60 minutes (76). Souza et al. (79) amplified the pressure in the maxillary chamber of the GLM system to accelerate glucose leakage from weeks to hours in order to decrease the risk of bacterial growth and longterm water evaporation, while maintaining the capacity to detect the leaking samples.

Michailesco et al. (72) used latex microspheres and showed that they can be used to simulate bacterial leakage and that smaller particles penetrate deeper than bacteria and vice versa.

-Protein microleakage test

Protein microleakage test is carried out using bovine serum albumin in a dual-chamber apparatus and calculated using a spectrophotometer (80-82).

Methodology: In order to evaluate leakage, bovine serum albumin marker is traced in a dual-chamber apparatus with Bradford indicator. Bradford indicator is used to determine the concentration of albumin leaking from the upper chamber into the lower chamber. The procedure relies on the formation of a complex between the dye, Brilliant Blue G, and proteins in solution. The subsequent formation of the protein-dye complex shifts the wavelength of maximum absorption of Coomassie Brilliant Blue $\mathrm{G}$ from 465 to $596 \mathrm{~nm}$. The absorption rate is proportional to the protein present (82).

Caffeine microleakage is another method with the use of a modified dual-chamber model; epoxy resin is used for sealing of the margins instead of cyanoacrylate glue and leaked caffeine content can be detected by high-performance liquid chromatography-tandem mass spectrometry (HPLC-MS/MS) (83) or a visible ultraviolet spectrophotometer (UV-VIS detectors) $(77,84)$. The caffeine detection limit was $2000 \mathrm{ng} \mathrm{mL}-1$, using UV-VIS, and 10 ng mL-1, using HPLC-MS/MS. HPLC-MS/MS can detect concentrations at least 1000 times lower (83).

-Electrochemical microleakage test

The electrochemical method relies on the diffusion of ions through very narrow spaces, with the results possibly depending on electrical laws (85). It is believed that the magnitude of the electrical current produced by ions diffusion, between two electrodes, is directly proportional to the amount of leakage. Changes in ion concentration can affect the results. Another parameter that can be measured in the electrochemical test is the electric resistance. Resistance and leakage are inversely related to each other. As the leakage increases, the electric resistance decreases.

-Methodology: The external surfaces of the teeth were completely covered with nail varnish, sparing the access opening and the apical foramen. The roots were mounted in silicon through the bottom of plastic cylinders, leaving the access open within the cylinder. The cylinders were filled with saline solution to serve as an electrolyte. The cylinders in association with the teeth were mounted in Petri dishes filled with the saline solution as an electrolyte. Only $2 \mathrm{~mm}$ of the root ends were immersed in the solution. To carry out measurements, a \#70 K-file was placed in each upper chamber and a stainless steel wire was inserted into the Petri dish. The electrode in each upper chamber was separately connected to the electrode in the lower chamber through an electric circuit with an $8-\mathrm{V}$ direct current power supply. The electrical conductivity in this circuit was measured in $\mu \mathrm{A}$ for each root.

Some researchers (86) applied two different types of metal as electrodes (stainless steel and copper). This procedure may lead to an electrical potential that creates between two electrodes and effects on our measurements. The results of electrochemical microleakage tests were very divergent. This may be partly attributed to differences in the composition of the electrolyte, electrode type and distance between the two electrodes, electrode thickness and electrical conductivity of the ionic solution.

-The radioisotope penetration method

The radioisotope penetration method is a qualitative method (87). In the analysis of results; its two-dimensional autoradiograph image is not representative of the three-dimensional image of micro-leakage. An isotope, such as $\mathrm{Ca}$, has an affinity to tooth structure or restorative materials leading to increased measurement errors. Moreover, isotopes can pass through tooth structure or restorative material flaws as a result of their tiny size; resulting in misinterpretation of leakage (88).

Copper ion has been introduced as a new leakage tracer. Copper sulfate diffusion method was used since copper ions are not naturally detected in tooth structures by conventional methods (87). CuSO4 solution was injected into the coronal segment of the specimens with a fine needle. After two days, the copper sulfate concentration in the solution was measured by an atomic absorption spectrometer (87).

-Animal experiments

Animal studies on dogs undergoing endodontic treatment with a minimum 8 months of follow-up is another technique, with radiographs being taken every 2 months and histologic examinations after completion of the followup period (89). More extensive and long-term studies are necessary to establish a better and more efficient system for microleakage studies.

-Three-dimensional method

CBCT (90) and SEM evaluation (91) can be used for evaluation of maximum and minimum amounts of voids and dentin diffusion of sealer in obturation materials and 
can be representative of leakage potential of endodontic materials.

Bond strength, push-out bond strength and bond durability (92) can reveal leakage potential of endodontic materials.

\section{Conclusions}

The complexity of the subject resulted in a reduced number of articles on "obturation and microleakage". However, it is important to obtain a tight seal in obturated root canals and it is necessary to conduct clinical or laboratory studies to assess the sealability of endodontic materials. The combination of all innovative technologies has allowed the clinicians to render the best care available and achieve the most predictable outcomes possible.

Therefore, the clinicians should adopt these technologies and use them in the most predictable and efficient way possible. Thus, prevention of microleakage paves the way for more predictable and successful endodontic outcomes.

All the methods mentioned above are useful if the study is performed strictly with a large sample size and proper control groups. However, further studies should be performed on the clinical relevance of microleakage tests and their reliability and correlation between different leakage assessment methodologies.

\section{References}

1. H Bhandi S, T S S. Comparative evaluation of sealing ability of three newer root canal obturating materials guttaflow, resilon and thermafil: an in vitro study. J Int Oral Health. 2013;5:54-65.

2. Lin LM, Rosenberg PA, Lin J. Do procedural errors cause endodontic treatment failure? J Am Dent Assoc. 2005;136:187-193; quiz 231.

3. Li G, Niu L, Zhang W, Olsen M, De-Deus G, Eid AA, et al. Ability of New Obturation Materials to Improve the Seal of the Root Canal System - A Review. Acta Biomater. 2014;10:1050-63.

4. Torabinejad M, Eby WC, Naidorf IJ. Inflammatory and immunological aspects of the pathogenesis of human periapical lesions. J Endod. 1985;11:479-88.

5. Stashenko P, Teles R, D’Souza R. Periapical inflammatory responses and their modulation. Crit Rev Oral Biol Med. 1998;9:498521.

6. Nair PN, Henry S, Cano V, Vera J. Microbial status of apical root canal system of human mandibular first molars with primary apical periodontitis after "one-visit" endodontic treatment. Oral Surg Oral Med Oral Pathol Oral Radiol Endod. 2005;99:231-52.

7. Nair PN. On the causes of persistent apical periodontitis: a review. Int Endod J. 2006;39:249-81.

8. Wu MK, Dummer PM, Wesselink PR. Consequences of and strategies to deal with residual post-treatment root canal infection. Int Endod J. 2006;39:343-56.

9. Carr GB, Schwartz RS, Schaudinn C, Gorur A, Costerton JW. Ultrastructural examination of failed molar retreatment with secondary apical periodontitis: an examination of endodontic biofilms in an endodontic retreatment failure. J Endod. 2009;35:1303-9.

10. Schaudinn C, Carr G, Gorur A, Jaramillo D, Costerton JW, Webster P. Imaging of endodontic biofilms by combined microscopy (FISH/ cLSM - SEM). J Microsc. 2009;235:124-7.

11. Ricucci D, Siqueira JF, Jr. Biofilms and apical periodontitis: study of prevalence and association with clinical and histopathologic findings. J Endod. 2010;36:1277-88.

12. Vera J, Siqueira JF, Jr., Ricucci D, Loghin S, Fernandez N, Flores
B, et al. One- versus two-visit endodontic treatment of teeth with apical periodontitis: a histobacteriologic study. J Endod. 2012;38:1040-52.

13. Wanted: a base of evidence. J Endod. 2007;33:1401-2.

14. Moher D, Liberati A, Tetzlaff J, Altman DG. Preferred reporting items for systematic reviews and meta-analyses: the PRISMA statement. PLoS medicine. 2009;6:e1000097.

15. Holland R, Murata SS, Barbosa HG, Garlipp O, de Souza V, Dezan Junior E. Apical seal of root canals with gutta-percha points with calcium hydroxide. Braz Dent J. 2004;15:26-9.

16. Valera MC, Camargo CH, Carvalho AS, Gama ER. In vitro evaluation of apical microleakage using different root-end filling materials. J Appl Oral Sci. 2006;14:49-52.

17. Almeida JF, Gomes BP, Ferraz CC, Souza-Filho FJ, Zaia AA. Filling of artificial lateral canals and microleakage and flow of five endodontic sealers. Int Endod J. 2007;40:692-9.

18. De Deus QD. Frequency, location, and direction of the lateral, secondary, and accessory canals. J Endod. 1975;1:361-6.

19. De-Deus G, Brandao MC, Leal F, Reis C, Souza EM, Luna AS, et al. Lack of correlation between sealer penetration into dentinal tubules and sealability in nonbonded root fillings. Int Endod J. 2012;45:64251.

20. Venturi M, Prati C, Capelli G, Falconi M, Breschi L. A preliminary analysis of the morphology of lateral canals after root canal filling using a tooth-clearing technique. Int Endod J. 2003;36:54-63.

21. Verissimo DM, do Vale MS. Methodologies for assessment of apical and coronal leakage of endodontic filling materials: a critical review. J Oral Sci. 2006;48:93-8.

22. Mandava P, Bolla N, Thumu J, Vemuri S, Chukka S. Microleakage evaluation around retrograde filling materials prepared using conventional and ultrasonic techniques. J Clin Diagn Res. 2015;9:Zc43-46.

23. Haghgoo R, Arfa S, Asgary S. Microleakage of CEM Cement and ProRoot MTA as Furcal Perforation Repair Materials in Primary Teeth. Iran Endod J. 2013;8:187-90.

24. Mente J, Ferk S, Dreyhaupt J, Deckert A, Legner M, Staehle HJ. Assessment of different dyes used in leakage studies. Clin Oral Investig. 2010;14:331-8.

25. Shahi S, Yavari HR, Rahimi S, Eskandarinezhad M, Shakouei S, Unchi M. Comparison of the sealing ability of mineral trioxide aggregate and Portland cement used as root-end filling materials. J Oral Sci. 2011;53:517-22.

26. Rahimi S, Shahi S, Lotfi M, Yavari HR, Charehjoo ME. Comparison of microleakage with three different thicknesses of mineral trioxide aggregate as root-end filling material. J Oral Sci. 2008;50:273-7.

27. Lotfi M, Vosoughhosseini S, Saghiri MA, Rahimi S, Zand V, Reyhani MF, et al. Effect of Synthetic Tissue Fluid on Microleakage of Grey and White Mineral Trioxide Aggregate as Root-End Filling Materials: An in vitro study. Sultan Qaboos Univ Med J. 2012;12:323-9. 28. Yavari H, Samiei M, Eskandarinezhad M, Shahi S, Aghazadeh M, Pasvey Y. An in vitro comparison of coronal microleakage of three orifice barriers filling materials. Iran Endod J. 2012;7:156-60.

29. Shahi S, Shakouie S, Rahimi S, Yavari HR, Mohammadi N, Abdolrahimi M. Comparison of apical microleakage using Ni-Ti with stainless steel finger spreaders. Iran Endod J. 2009;4:149-51.

30. Shahi S, Zand V, Oskoee SS, Abdolrahimi M, Rahnema AH. An in vitro study of the effect of spreader penetration depth on apical microleakage. J Oral Sci. 2007;49:283-6.

31. Lucena-Martin C, Ferrer-Luque CM, Gonzalez-Rodriguez MP, Robles-Gijon V, Navajas-Rodriguez de Mondelo JM. A comparative study of apical leakage of Endomethasone, Top Seal, and Roeko Seal sealer cements. J Endod. 2002;28:423-6.

32. Ahlberg KM, Assavanop P, Tay WM. A comparison of the apical dye penetration patterns shown by methylene blue and india ink in root-filled teeth. Int Endod J. 1995;28:30-4.

33. Zmener O, Pameijer CH, Macri E. Evaluation of the apical seal in root canals prepared with a new rotary system and obturated with a methacrylate based endodontic sealer: an in vitro study. J Endod. 2005;31:392-5.

34. Camps J, Pashley D. Reliability of the dye penetration studies. J Endod. 2003;29:592-4. 
35. Lahor-Soler E, Miranda-Rius J, Brunet-Llobet L, Farre M, Pumarola J. In vitro study of the apical microleakage with resilon root canal filling using different final endodontic irrigants. J Clin Exp Dent. 2015;7:e212-7.

36. Mokhtari H, Shahi S, Janani M, Reyhani MF, Mokhtari Zonouzi HR, Rahimi S, et al. Evaluation of apical leakage in root canals obturated with three different sealers in presence or absence of smear layer. Iran Endod J. 2015;10:131-4.

37. Girish CS, Ponnappa K, Girish T, Ponappa M. Sealing ability of mineral trioxide aggregate, calcium phosphate and polymethylmethacrylate bone cements on root ends prepared using an Erbium: Yttriumaluminium garnet laser and ultrasonics evaluated by confocal laser scanning microscopy. J Conserv Dent. 2013;16:304-8.

38. dos Santos GL, Beltrame AP, Triches TC, Ximenes-Filho M, Baptista D, Bolan M. Analysis of microleakage of temporary restorative materials in primary teeth. J Indian Soc Pedod Prev Dent. 2014;32:130-4.

39. Srikumar GP, Varma KR, Shetty KH, Kumar P. Coronal microleakage with five different temporary restorative materials following walking bleach technique: An ex-vivo study. Contemp Clin Dent. 2012;3:421-6.

40. Cueva-Goig R, Forner-Navarro L, Llena-Puy MC. Microscopic assessment of the sealing ability of three endodontic filling techniques. J Clin Exp Dent. 2016;8:e27-31.

41. Robertson D, Leeb IJ, McKee M, Brewer E. A clearing technique for the study of root canal systems. J Endod. 1980;6:421-4.

42. Rahimi S, Shahi S, Yavari HR, Reyhani MF, Ebrahimi ME, Rajabi E. A stereomicroscopy study of root apices of human maxillary central incisors and mandibular second premolars in an Iranian population. $\mathrm{J}$ Oral Sci. 2009;51:411-5.

43. Rahimi S, Milani AS, Shahi S, Sergiz Y, Nezafati S, Lotfi M. Prevalence of two root canals in human mandibular anterior teeth in an Iranian population. Indian J Dent Res. 2013;24:234-6.

44. Malvar M, Gomes M, Pereira M. Root canal anatomy study of lower incisors by clearing technique. J Bras Endod. 2002;3:202-7.

45. Kontakiotis EG, Georgopoulou MK, Morfis AS. Dye penetration in dry and water-filled gaps along root fillings. Int Endod J. 2001;34:133-6.

46. Chitsazi MT, Pourabbas R, Jafari F, Jabari Khameneh H. Comparison of subgingival plaque removal using hand curettes, magnetostrictive ultrasonic scalers and air polishing devices with and without $\mathrm{Na}$ HCO3 abrasive powder: an ex vivo study. Journal of Periodontology \& Implant Dentistry. 2009;1:31-5.

47. Brandao C, De Moraes I, Bramante C. Apical sealing ability of ionomeric endodontic sealers. Rev FOB. 2001;9:29-34.

48. Kersten HW, Moorer WR. Particles and molecules in endodontic leakage. Int Endod J. 1989;22:118-24.

49. Schafer E, Olthoff G. Effect of three different sealers on the sealing ability of both thermafil obturators and cold laterally compacted GuttaPercha. J Endod. 2002;28:638-42.

50. Souza EM, Pappen FG, Shemesh H, Bonanato-Estrela C, BonettiFilho I. Reliability of assessing dye penetration along root canal fi1lings using methylene blue. Aust Endod J. 2009;35:158-63.

51. Barthel CR, Moshonov J, Shuping G, Orstavik D. Bacterial leakage versus dye leakage in obturated root canals. Int Endod J. 1999;32:370-5.

52. Valois C, De Castro A. Comparison of the apical sealing ability of four root canal sealers. J Bras Endod. 2002;3:317-22.

53. Wu MK, De Gee AJ, Wesselink PR. Fluid transport and dye penetration along root canal fillings. Int Endod J. 1994;27:233-8.

54. Wimonchit S, Timpawat S, Vongsavan N. A comparison of techniques for assessment of coronal dye leakage. J Endod. 2002;28:1-4.

55. Agrafioti A, Tzimpoulas N, Chatzitheodoridis E, Kontakiotis EG. Comparative evaluation of sealing ability and microstructure of MTA and Biodentine after exposure to different environments. Clin Oral Investig 2015 .

56. Tabrizizade M, Asadi Y, Sooratgar A, Moradi S, Sooratgar H, Ayatollahi F. Sealing ability of mineral trioxide aggregate and calcium- enriched mixture cement as apical barriers with different obturation techniques. Iran Endod J. 2014;9:261-5.

57. Onay EO, Gogos C, Ungor M, Economides N, Lyssaris V, Ogus E, et al. Effect of Er,Cr:YSGG laser irradiation on apical sealing ability of calcium silicatecontaining endodontic materials in root-end cavities. Dent Mater J. 2014;33:570-5.

58. Bidar M, Sadeghalhoseini N, Forghani M, Attaran N. Effect of the smear layer on apical seals produced by two calcium silicate-based endodontic sealers. Journal of oral science. 2014;56:215-9.

59. Pommel L, Camps J. Effects of pressure and measurement time on the fluid filtration method in endodontics. J Endod. 2001;27:256-8. 60. Garip H, Garip Y, Orucoglu H, Hatipoglu S. Effect of the angle of apical resection on apical leakage, measured with a computerized fluid filtration device. Oral Surg Oral Med Oral Pathol Oral Radiol Endod. 2011;111:e50-5.

61. Shetty KV, Jhajharia K, Chaurasia VR, Jhamb A, Rohra V, Sharma AM. An in vitro evaluation of the effect of dentin deproteinization on coronal microleakage in endodontically treated teeth. J Int Soc Prev Community Dent. 2014;4:S187-92.

62. Maltezos C, Glickman GN, Ezzo P, He J. Comparison of the sealing of Resilon, Pro Root MTA, and Super-EBA as root-end filling materials: a bacterial leakage study. J Endod. 2006;32:324-7.

63. Yavari HR, Samiei M, Shahi S, Aghazadeh M, Jafari F, Abdolrahimi M, et al. Microleakage comparison of four dental materials as intra-orifice barriers in endodontically treated teeth. Iran Endod J. 2012;7:25-30.

64. Shahi S, Jeddi Khajeh S, Rahimi S, Yavari HR, Jafari F, Samiei M, et al. Effect of different mixing methods on the bacterial microleakage of calcium-enriched mixture cement. Minerva Stomatol. 2016;65:26975 .

65. Britto LR, Grimaudo NJ, Vertucci FJ. Coronal microleakage assessed by polymicrobial markers. J Contemp Dent Pract. 2003;4:1-10. 66. Chailertvanitkul P, Saunders WP, Saunders EM, MacKenzie D. An evaluation of microbial coronal leakage in the restored pulp chamber of root-canal treated multirooted teeth. Int Endod J. 1997;30:318-322. 67. Reyhani MF, Yavari H, Ghasemi N, Rahimi S, Barhaghi MH, Mokhtari H, et al. Comparing the Coronal Seal of Different Thicknesses of MTA with Gutta-Percha after Post Space Preparation. The Scientific World Journal. 2015;2015:708639.

68. Reyhani MF, Ghasemi N, Rahimi S, Milani AS, Barhaghi MH, Azadi A. Apical microleakage of AH Plus and MTA Fillapex(R) sealers in association with immediate and delayed post space preparation: a bacterial leakage study. Minerva Stomatol. 2015;64:129-34.

69. Jafari F, Sobhani E, Samadi-Kafil H, Pirzadeh A, Jafari S. In vitro evaluation of the sealing ability of three newly developed root canal sealers: A bacterial microleakage study. J Clin Exp Dent. 2016;8:e561-5.

70. Carratu P, Amato M, Riccitiello F, Rengo S. Evaluation of leakage of bacteria and endotoxins in teeth treated endodontically by two different techniques. J Endod. 2002;28:272-5.

71. Miletic I, Prpic-Mehicic G, Marsan T, Tambic-Andrasevic A, Plesko S, Karlovic Z, et al. Bacterial and fungal microleakage of AH26 and AH Plus root canal sealers. Int Endod J. 2002;35:428-32.

72. Michailesco P, Boudeville P. Calibrated latex microspheres percolation: a possible route to model endodontic bacterial leakage. J Endod. 2003;29:456-62.

73. Tang HM, Torabinejad M, Kettering JD. Leakage evaluation of root end filling materials using endotoxin. J Endod. 2002;28:5-7.

74. Williamson AE, Dawson DV, Drake DR, Walton RE, Rivera EM. Effect of root canal filling/sealer systems on apical endotoxin penetration: a coronal leakage evaluation. J Endod. 2005;31:599-604.

75. Kim SY, Ahn JS, Yi YA, Lee Y, Hwang JY, Seo DG. Quantitative microleakage analysis of endodontic temporary filling materials using a glucose penetration model. Acta Odontol Scand. 2015;73:137-43.

76. Leal F, De-Deus G, Brandao C, Luna A, Souza E, Fidel S. Similar sealability between bioceramic putty ready-to-use repair cement and white MTA. Braz Dent J. 2013;24:362-6.

77. Xu Q, Fan MW, Fan B, Cheung GS, Hu HL. A new quantitative 
method using glucose for analysis of endodontic leakage. Oral Surg Oral Med Oral Pathol Oral Radiol Endod. 2005;99:107-11.

78. Bernabé PFE, Gomes-Filho JE, Bernabé DG, Nery MJ, OtoboniFilho JA, Dezan-Jr E, et al. Sealing Ability of MTA Used as a Root End Filling Material: Effect of the Sonic and Ultrasonic Condensation. Braz Dent J. 2013;24:107-110.

79. Shemesh H, Souza E, Wu MK, Wesselink P. Glucose reactivity with filling materials as a limitation for using the glucose leakage model. Inter Endod J. 2008;41:869-72.

80. Shahi S, Rahimi S, Hasan M, Shiezadeh V, Abdolrahimi M. Sealing ability of mineral trioxide aggregate and Portland cement for furcal perforation repair: a protein leakage study. J Oral Sci. 2009;51:601-6. 81. Saghiri MA, Lotfi M, Saghiri AM, Vosoughhosseini S, Fatemi A, Shiezadeh V, et al. Effect of $\mathrm{pH}$ on sealing ability of white mineral trioxide aggregate as a root-end filling material. J Endod. 2008;34:1226-9.

82. Zarenejad N, Asgary S, Ramazani N, Haghshenas MR, Rafiei A, Ramazani M. Coronal microleakage of three different dental biomaterials as intra-orifice barrier during nonvital bleaching. Dent Res J (Isfahan). 2015;12:581-8.

83. Michelotto AL, Gasparetto JC, Campos FR, Sydney GB, Pontarolo R. Applying liquid chromatography-tandem mass spectrometry to assess endodontic sealer microleakage. Braz Oral Res. 2015;29:1-7.

84. Shemesh H, Wu MK, Wesselink PR. Leakage along apical root fillings with and without smear layer using two different leakage models: a two-month longitudinal ex vivo study. Int Endod J. 2006;39:968-76. 85. Pommel L, Jacquot B, Camps J. Lack of correlation among three methods for evaluation of apical leakage. J Endod. 2001;27:347-50.

86. Jacobson SM, von Fraunhofer JA. The investigation of microleakage in root canal therapy. An electrochemical technique. Oral Surg Oral Med Oral Pathol. 1976;42:817-23.

87. Modaresi J, Baharizade M, Shareghi A, Ahmadi M, Daneshkazemi A. Copper ion as a new leakage tracer. J Dent (Shiraz). 2013; 14:155-9.

88. Delivanis PD, Chapman KA. Comparison and reliability of techniques for measuring leakage and marginal penetration. Oral Surg Oral Med Oral Pathol. 1982;53:410-6.

89. Yamauchi S, Shipper G, Buttke T, Yamauchi M, Trope M. Effect of orifice plugs on periapical inflammation in dogs. J Endod. 2006;32:524-6.

90. Gupta R, Dhingra A, Panwar NR. Comparative Evaluation of Three Different Obturating Techniques Lateral Compaction, Thermafil and Calamus for Filling Area and Voids Using Cone Beam Computed Tomography: An Invitro study. J Clin Diagn Res. 2015;9:Zc15-17.

91. Moura-Netto C, Guglielmi Cde A, Mello-Moura AC, Palo RM, Raggio DP, Caldeira CL. Nd:YAG laser irradiation effect on apical intracanal dentin - a microleakage and SEM evaluation. Braz Dent J. 2011;22:377-81.

92. Atash Biz Yeganeh L, Seyed Tabai E, Mohammadi Basir M. Bonding Durability of Four Adhesive Systems. J Dent (Tehran). 2015;12:563-70.

\section{Conflict of Interest}

The authors have declared that no conflict of interest exist. 